\title{
KARAKTERISASI MICRORNA TRIPLE HELIX MELALUI METODE HYDROGEL SCAFFOLD SPESIFIK TERHADAP MICRORNA-26A DAN HSA-MICRORNA-15A: MODALITAS KURATIF MUTAKHIR PADA PENYAKIT KATARAK
}

\author{
Nisrina Hanifah Afnan ${ }^{1}$, Endah Sari Ratna Kumala ${ }^{1}$, Mochamad Afifudin ${ }^{1}$, \\ ${ }^{1}$ Medical Education Study Program, Faculty of Medicine, Indonesian Islamic University, Yogyakarta \\ e-mail: ninaafnan14@gmail.com
}

\begin{abstract}
Cataract is an eye disease that is marked by it decrease in lens transparency. Cataract is a major cause of blindness. Data The World Health Organization (WHO) in 2010 showed that there were 285 million people have visual impairments worldwide, 39 million of them blindness where $33 \%$ of them are caused by cataracts. Governance cataracts are currently limited to surgical efforts and administration of eye drops as antioxidant. But both have flaws because of the risk of complications limited ocular and lens penetrating ability. Therefore, the author reviewed the potential for triple helix microRNA characterization through specific Hydrogel Scaffold methods against microRNA-26a and hsa-microRNA-15a as the latest curative modalities on cataract disease. microRNA is a non coding RNA molecule consisting of 22 nucleotide. microRNA is known to have a specific target gene so it will increase the effectiveness of therapy in cataracts. The method used in this writing is a study of literature. The author reviews various sources, the majority come from a global journal. The author enters several keywords such as cataract, microRNA, triplex nanoparticle, and Hydrogel Scaffold. The website is used including nature, sciencedirect, pubmed, and ebsco. After extraction based on the inclusion and exclusion criteria that have been determined, the journal is then analyzed and synthesized whose results are written in this review literature. based on literature obtained, microRNA-26a has decreased expression in cataract cases. So that when microRNA-26a is transfected, there will be an increase in regulation which can increase the positive effect on inhibiting the process of fibrosis on

cataract pathomechanism mediated by Notch / Jagged-1. Meanwhile, microRNA-15a overexpresses, so that when transfected antagomir microRNA-15a, then this microRNA will decrease and give negative feedback so the expression of bcl-2 and mcl-1 as antiapoptotic and antioxidant proteins will be increased. To increase its stability, both microRNA-26a and antagomir microRNA-15a will be formed into a triple helix RNA structure through addition dendrimer with the Hydogel Scaffold method. This allows the microRNA become more stable in circulation and can be released in specific genes. By therefore, through the triple helix RNA characterization specific to microRNA-15a and microRNA-26a, cataract therapy is expected to be more effective and efficient.
\end{abstract}

Keywords

: cataracts, triple helix microRNA, microRNA-15a, microRNA-26a

\begin{abstract}
Abstrak
Katarak merupakan salah satu penyakit mata yang ditandai dengan adanya penurunan transparansi lensa. Katarak merupakan penyebab utama dari kebutaan. Data World Health Organization (WHO) pada tahun 2010 menunjukkan bahwa terdapat 285 juta orang memiliki gangguan pengelihatan di seluruh dunia, 39 juta diantaranya mengalami kebutaan dimana 33\% diantaranya disebabkan karena katarak. Tatalaksana katarak saat ini terbatas pada upaya pembedahan dan pemberian obat tetes mata sebagai antioksidan. Namun keduanya memiliki kekuarangan karena adanya risiko komplikasi ocular dan kemampuan menembus lensa yang terbatas. Oleh karena itu, penulis mereview potensi karakterisasi microRNA triple helix melalui metode Hydrogel Scaffold spesifik terhadap microRNA-26a dan hsa-microRNA-15a sebagai modalitas kuratif mutakhir pada penyakit katarak. microRNA merupakan molekul non coding RNA yang terdiri dari 22 nukleotida. microRNA diketahui memiliki target gen yang spesifik sehingga akan meningkatkan efektivitas terapi pada penyakit katarak. Metode yang digunakan dalam penulisan ini adalah studi literatur. Penulis mereview berbagai sumber yang mayoritas berasal dari jurnal global. Penulis memasukkan beberapa kata kunci seperti cataract, microRNA, triplex nanoparticle, dan Hydrogel Scaffold. Adapun website yang digunakan antara lain nature, sciencedirect, pubmed, dan ebsco. Setelah dilakukan ekstraksi berdasarkan kriteria inklusi dan eksklusi yang telah ditentukan, jurnal kemudian dianalisis dan disintesis yang hasilnya tertulis dalam literature review ini. Berdasarkan literature yang didapatkan, microRNA-26a mengalami penurunan ekspresi pada kasus katarak. Sehingga ketika microRNA-26a ditransfeksikan, maka akan terjadi peningkatan regulasi yang dapat meningkatkan efek positif
\end{abstract}


terhadap penghambatan proses fibrosis pada patomekanisme katarak yang dimediasi oleh Notch/Jagged-1. Sementara itu, microRNA- 15a mengalami overekspresi, sehingga ketika ditransfeksikan antagomir microRNA15a, maka microRNA ini akan mengalami penurunan dan memberikan feedback negatif sehingga ekspresi bcl-2 dan mcl-1 sebagai protein antiapoptosis dan antioksidan akan meningkat. Untuk meningkatkan kestabilannya, baik microRNA-26a dan antagomir microRNA-15a akan dibentuk menjadi struktur RNA triple helix melalui penambahan dendrimer dengan metode Hydogel Scaffold. Hal ini memungkinkan microRNA tersebut menjadi lebih stabil dalam sirkulasi dan dapat terlepas pada gen yang spesifik. Oleh karena itu, melalui karakterisasi RNA triple helix spesifik terhadap microRNA-15a dan microRNA-26a, diharapkan terapi pada katarak menjadi lebih efektif dan efisien.

Kata kunci : katarak, microRNA triple helix, microRNA-15a, microRNA-26a

\section{PENDAHULUAN}

Katarak merupakan salah satu penyakit pada mata yang ditandai dengan hilangnya transparansi pada lensa ${ }^{1}$. Penyakit ini merupakan penyebab terbesar dari kebutaan ${ }^{2}$. Data World Health Organization (WHO) pada tahun 2010 menunjukkan bahwa terdapat 285 juta orang memiliki gangguan pengelihatan di seluruh dunia, 39 juta diantaranya mengalami kebutaan ${ }^{3}$. Katarak sendiri menyumbang sebesar $33 \%$ penyebab kebutaan. Sebanyak $47,8 \%$ penduduk dunia menderita katarak pada usia diatas 50 tahun. Di Eropa, penderita katarak dengan usia 50-62 tahun sebanyak 5\% dan 30\% untuk usia 60-69 tahun. Penduduk dengan usia lebih dari 70 tahun sebanyak 64\%. Data tersebut menunjukkan bahwa usia menjadi salah satu etiopatogenesis tertinggi dari penyakit katarak. ${ }^{4}$ Katarak merupakan penyebab utama kebutaan di Indonesia. Data tersebut diperoleh melalui metode Rapid Assasment of Avoidable Cataract (RAAB) yang dilakukan di 15 provinsi di Indonesia, prevalensi kebutaan mencapai $4,4 \%$ pada populasi usia 50 tahun dan 64 95\% diantaranya disebabkan oleh katarak. Diperkirakan setiap tahunnya penderita katarak bertambah sebesar $0.1 \%$ dari jumlah penduduk. Operasi Katarak merupakan cara penanggulangan buta akibat katarak. Kebutuhan operasi katarak di Indonesia mencapai 240.000 orang setiap tahunnya sementara kemampuan untuk melakukan operasi katarak baru mencapai 180.000/tahun. ${ }^{5}$ Biaya operasi katarak pada negara di Eropa berbedabeda. Negara Denmark memiliki biaya operasi katarak sebesar $€ 714$ per orang atau sebesar Rp. 11.540.000 dan di Italia sebesar $€ 437$ atau Rp. 7.063.00. Sementara pada negara Inggris biaya yang dikeluarkan untuk lensa adalah $€ 157$ atau Rp. 2.536.000. ${ }^{4}$

Tatalaks ana pada penyakit katarak dapat ditempuh dengan pembedahan/ operasi maupun pemberian obat-obatan. Sampai saat ini, pembedahan menjadi metode yang paling efektif dalam menangani katarak. Meskipun demikian, terapi yang terbilang mahal tersebut masih sulit diterapkan pada Negara berkembang. Selain karena biaya yang mahal, tingkat kesadaran yang rendah serta minimnya tenaga ahli bedah mata yang professional juga menjadi hambatan. Hal inilah yang menjadikan outcome terapi pembedahan katarak pada Negara berkembang buruk. Pemerintah setempat biasanya juga menerapkan pembedahan insisi ekstrakapsular kecil yang memiliki tingkat efisiensi yang rendah. ${ }^{6}$ Selain itu, terapi bedah juga masih sulit menghasilkan prognosis yang baik pada kasus dense brunescent cataract (katarak dengan tingkat keparahan tinggi; berat). Operasi katarak dapat menimbulkan beberapa komplikasi intraoperatif, seperti kehilangan vitreous dan pendarahan pada anterior chamber. Bahkan pada kasus-kasus tertentu juga dapat menimbulkan cedera endothelial pada kornea, rupture kapsul posterior, dan dialisis zonular. ${ }^{7}$ Disisi lain, terdapat beberapa obat tetes mata yang dapat 
digunakan untuk menurunkan progresi patofisiologi katarak. Obat tetes mata ini hanya digunakan pada kasus-kasus katarak yang bersifat simptomatik atau sebagai pencegahan pada lanjut usia. Namun sebagian besar obat tetes mata yang sering digunakan, seperti L-carnosine, tidak dapat memprenetrasi mata dengan baik. Obat tersebut hanya akan menembus kornea dan berhenti didepan chamber atau lokasi katarak berada, sehingga akan menurunkan efek antioksidan yang dikandungnya. ${ }^{8}$ Sementara katarak kongenital atau yang disebabkan karena faktor genetik, hanya dapat diterapi dengan pembedahan dan beberapa terapi paliatif. ${ }^{9}$

Oleh karena itu, penulis mengusulkan intervensi penyakit katarak dengan terapi berbasis RNA. Dalam hal ini, penulis mereview potensi karakterisasi microRNA triple helix melalui metode Hydrogel Scaffold spesifik terhadap microRNA-26a dan hsa-microRNA-15a sebagai modalitas kuratif mutakhir pada penyakit katarak. microRNA merupakan molekul non coding RNA yang terdiri dari 22 nukleotida. ${ }^{10}$ microRNA dapat menargetkan gen spesifik. ${ }^{11}$ Pada kasus katarak, terdapat beberapa microRNA yang mengalami overekspresi seperti hsa-microRNA-15a dan beberapa microRNA yang mangalami penurunan ekspresi seperti microRNA26a. ${ }^{12}$ Terapi menggunakan microRNA banyak digunakan pada penyakit-penyakit yang berkaitan dengan proses interaksi gen dengan persinyalan seluler seperti kanker dan beberapa penyakit neurodegeneratif. ${ }^{13,14}$ Namun, penerapan microRNA pada klinis masih terbatas karena memiliki stabilitas dan waktu paruh yang rendah. ${ }^{15}$ Oleh karena itu, diperlukan metode formulasi terbaru guna meningkatkan efikasi farmakokinetik microRNA. Dalam hal ini, penulis mereview potensi pembentukan struktur triplex atau microRNA triple helix yang dapat disintesis menggunakan metode hydrogel scaffold. Melalui intervensi microRNA triplex yang tersusun dari microRNA-15a dan microRNA-26a, diharapkan modalitas kuratif pada penyakit katarak menjadi lebih efektif dan efisien.

\section{HASIL DAN PEMBAHASAN}

Katarak merupakan penyakit yang memiliki banyak faktor risiko seperti faktor genetik, jenis kelamin, etnis, penuaan, diare atau dehidrasi, hipertensi, merokok, stress oksidatif, akumulasi profil lipid berlebih, dan trauma. Pada faktor genetic, ditemukan data bahwa $1 / 3$ dari penyakit katarak kongenital bersifat herediter. Ciri khas dari katarak akibat faktor ini adal disertai dengan mikroopthalmia, aniridia, anomaly chamber anterior, degenerasi retina, dan sindrom Lowe. Gen yang dipercaya menjadi penyebab dari katarak kongenital adalah gen PITX3. ${ }^{16,17}$ Jenis kelamin juga menunjukkan data yang menarik dimana katarak pada wanita memiliki tingkat insidensi yang lebih tinggi dibanding pada pria. Namun, hal ini disebabkan karena berkurangnya kadar estrogen tubuh pada wanita menopause. ${ }^{18,19}$ Sementara itu, hipertensi juga dapat menjadi faktor risiko katarak, karena pada kasus hipertensi terjadi penurunan kemampuan dari pompa ion $\mathrm{Na}$ K ATPase. Hal ini secara tidak langsung dapat menimbulkan kekeruhan atau opasifikasi pada lensa. ${ }^{20,21,22,23}$

Dari sekian banyak faktor risiko katarak, pada dasarnya, mayoritas penderita katarak disebabkan karena faktor penuaan. ${ }^{24}$ Salah satu mekanisme yang mendasarinya adalah terjadinya penurunan elastisitas. Peningkatan daya refraksi lensa yang terjadi dengan akomodasi diakibatkan oleh perubahan ketebalan dan kelengkungan lensa, yang disebabkan oleh kontraksi otot siliaris. Pada pengamatan Scheimpflug dan MRI menunjukkan bahwa 90 persen peningkatan ketebalan lensa aksial disebabkan oleh penebalan inti lensa. Namun, peningkatan kekakuan lensa dimulai sejak lahir. Hingga usia sekitar 40 tahun, akan ada peningkatan kekakuan lensa yang terus-menerus seiring bertambahnya usia. $^{25}$ Selain itu, semakin 
bertambahnya usia, maka akan terjadi penurunan aktivitas chaperone $\alpha$-crystallin . Protein ini akan mencapai aktivitas fisiologis maksimum pada dekade kelima, setalah itu akan terjadi penurunan dan menyumbang peningkatan agregasi protein tidak larut, hamburan cahaya dan hilangnya transparansi lensa. ${ }^{26}$ Mekanisme ini merupakan prekursor patomekanisme katarak. Perubahan diperkuat oleh berkurangnya ketersediaan antioksidan yang mampu melindungi protein tersebut yang rentan terhadap oksidasi. Di atas usia 50 tahun, hampir semua $\alpha$ - crystallin ditemukan dalam fraksi WIS dari inti lensa. ${ }^{26,27}$ Kondisi ini sejatinya akan mengarah pada proses fibrogenesis (pembentuk jaringan ikat pada lensa) yang seringkali dimediasi oleh TGF- $\beta{ }^{28}$

Fibrosis merupakan penyakit kronis yang dapat muncul di berbagai organ dan memiliiki rerata harapan hidup yang lebih rendah dibanding penyakit kanker.27,28 Epithelial to Mesenchymal Transition (EMT) merupakan aspek terpenting dalam kejadian fibrosis, baik fibrosis pulmoner, renal, hepatic, maupun okular. ${ }^{29}$ Dalam jaringan fibrosis, terjadi akumulasi miofibroblast yang mensekresikan kolagen berlebih sehingga akan merusak fungsi organ. Kejadian fibrosis pada lensa terbagi menjadi 2, yakni anterior subcapsular cataract (ASC) dan posterior capsule opacification (PCO). ASC merupakan katarak primer yang ditandai dengan terhamburnya cahaya pada area fibrotik di kapsul lensa anterior. Beberapa penyebab ASC adalah trauma ocular, inflamasi, dan iritasi. Sementara itu, PCO merupakan katarak sekunder yang biasanya muncul sebagai komplikasi dari operasi katarak..$^{30,31}$

Mekanisme seluler ASC dan PCO ditandai dengan adanya proliferasi, migrasi, dan EMT sel epithelial lensa, yang mengakibatkan terjadinya transisi dari sel epitel ke fibroblast dan produksi protein matriks ekstraseluler (ECM) seperti kolagen tipe I dan IV, serta fibronectin. Pada akhirnya, protein tersebut akan membentuk plak subkapsular di area kapsul lensa anterior atau posterior. ${ }^{32}$

Disisi lain, terdapat regulasi persinyalan intraseluler yang dimediasi oleh Notch pada beberapa penyakit yang ditandai dengan adanya fibrosis. Inaktivasi Notch secara tidak langsung dapat membantu menurunkan risiko resistensi obat dan mengembalikan fenotip EMT yang terinaktivasi. ${ }^{33}$ Notch memiliki 4 reseptor (Notch 1-4) dan 5 ligan (Jagged 1-2, Deltalike 1, Delta-like 3-4). Ketika Notch berikatan dengan ligannya, reseptor Notch akan terpotong oleh $\gamma$-sekretase sehingga Notch Intracellular Domain (NICD) tersintesis. NCID akan bertranslokasi ke nukleus sehingga dapat meregulasi penurunan gen target seperti Hes dan Hey. ${ }^{34}$ Beberapa penelitian sebelumnya telah menunjukan bahwa melalui penargetan Notch, proses fibrosis di ginjal dan sel epithelial alveolar dapat dihambat melalui mekanisme yang dimediasi oleh Jagged-1//Notch guna menginhibisi TGF$\beta 1$, sehingga EMT dapat terhambat. ${ }^{35,36}$

Sebagai upaya penargetan Notch, penulis mengusulkan digunakannya microRNA. microRNA merupakan molekul non-coding RNA yang terdiri dari 22 nukleotida. microRNA dapat diaktivasi melalui beberapa proses. Pertama, single stranded Stem akan dikenali oleh protein DGCR8 dan Drocha untuk memotong RNA menjadi prekursor microRNA. Prekursor ini kemudian akan ditransfer ke sitosol melalui bantuan exportin-5. Setelah bertemu dengan enzim Dicer yang akan mengubah microRNA double stranded menjadi microRNA single stranded, bersama dengan protein argonout, microRNA akan membentuk RISC atau RNA induce silencing complex. RISC merupakan microRNA yang sudah aktif dan dapat melakukan silencing melalui dua proses, yakni dengan pemotongan target massanger rna dan inhibisi translasi melalui pengikatan subunit ribosom. ${ }^{37,38}$

Beberapa microRNA yang telah terbukti dapat meregulasi EMT adalah microRNA200, microRNA-29b, microRNA-34a, dan 
microRNA-491-5p. ${ }^{39,40,41,42}$ Disisi lain, famili microRNA-26 yang matur (microRNA-26a dan microRNA-26b) telah terbukti dapat menjadi tumor supresor pada kasus karsinoma hepatosellular, kanker payudara, dan glioma. ${ }^{43,44,45,46}$ microRNA26b diketahui lebih spesifik dengan menargetkan Prostaglandin-Endoperoxide Synthase 2 (PTGS2) dan Solute Carrier Family 7 Member 11 (SLC7A11) guna menginduksi apoptosis dan menghambat migrasi serta invasi sel kanker dengan EPH receptor A2 (EphA2). Pada patologi fibrosis, berdasarkan penelitian Liang et al, microRNA-26 melalui penargetan Smad4 dapat menghambat translokasi nuklear pSmad3 dan EMT. microRNA-26a secara spesifik juga terbukti dapat menghambat fibrosis jantung dan fibrosis pulmoner idiopatik melalui penargetan Kolagen tipe 1, Connective Tissue Growth Factor (CTGF), dan High Mobility Group AThook 2 (HMGA2). Sementara itu, penelitian Dong et al pada tahun 2014 menunjukkan bahwa ekspresi microRNA$26 \mathrm{~b}$ secara signifikan mengalami penurunan pada kasus PCO dan overekspresi dari microRNA-26b dapat mengcegah LEC-EMT melalui penargetan Smad4 dan Cyclooxygenase-2 (COX2). ${ }^{47,48,49,50}$
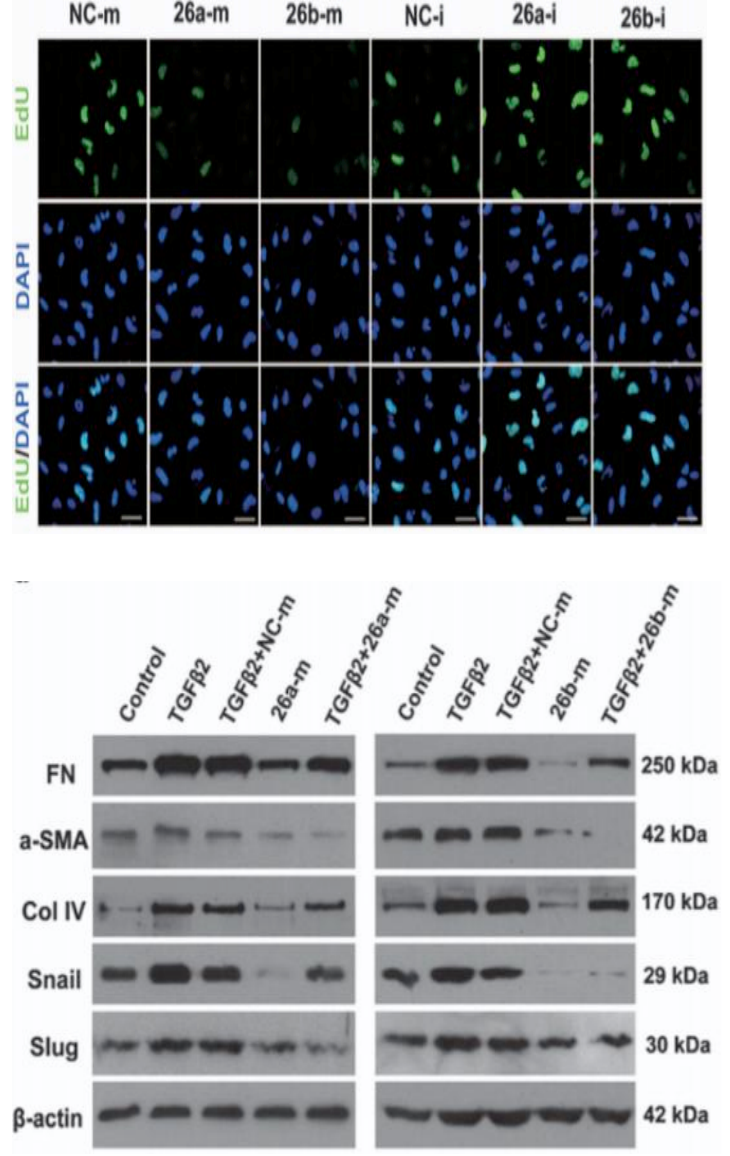

Gambar 1. Analisis pengaruh transfeksi microRNA-26a/b mimic terhadap kultur sel Lens Epithelial Cell (LEC) SRA01/04. ${ }^{51}$

Penelitian Chen et al pada tahun 2017 telah mengkonfirmasi bahwa microRNA26a/b menjadi salah satu dari 223 microRNA yang mengalamai underekspresi pada kasus ASC. Penelitian tersebut juga menunjukkan bahwa microRNA-26a/b mengalami penurunan respon pada perlakuan TGF- $\beta$ pada jam ke 24 dan 48 hingga $35 \%$ dan $39 \%{ }^{51}$ 

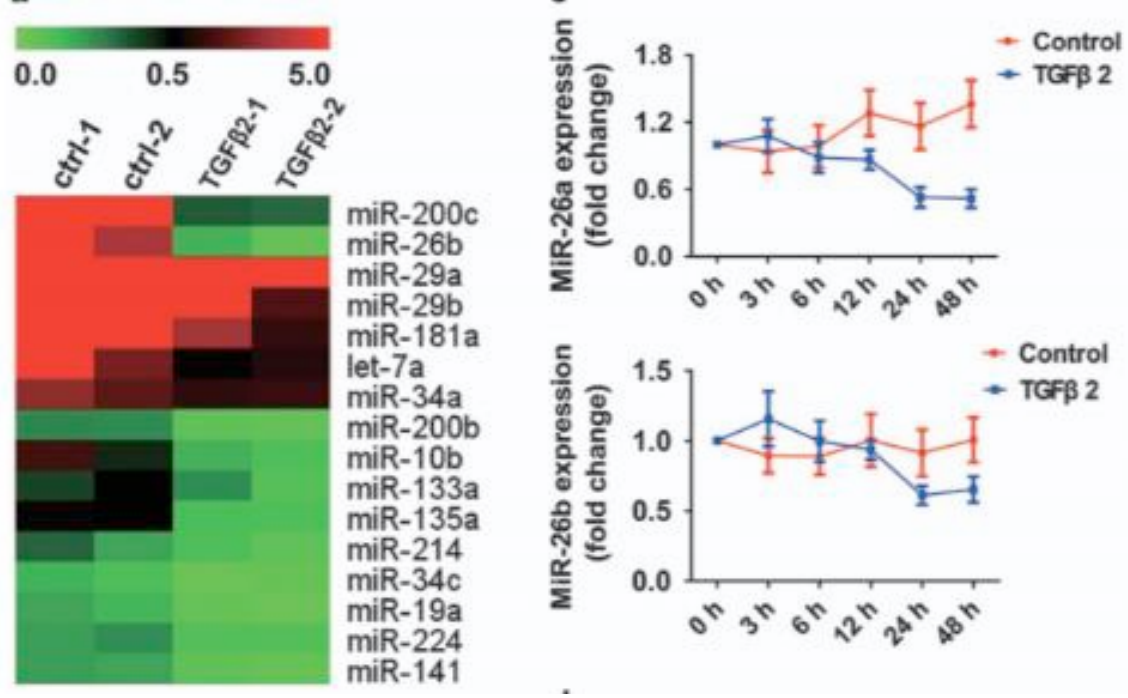

Gambar 2. Tingkat ekspresi microRNA pada sel ASC. Respon microRNA-26-a/b terhadap TGF- $\beta{ }^{51}$

Penelitian Chen et al. tersebut juga menganalisis pengaruh transfeksi microRNA-26a/b mimic terhadap kultur sel Lens Epithelial Cell (LEC) SRA01/04. Hasil analisis Real-time PCR menunjukkan bahwa microRNA tersebut mengalami overekspresi pada SRA01/04 dibanding perlakuan inhibitor oligonukleotida dan kelompok kontrol negatif yang mana hal ini menunjukkan spesifisitas dari microRNA tersebut. Analisis Wound Healing assay juga menunjukkan bahwa microRNA 26a/b juga dapat menghambat proliferasi dan migrasi LEC yang ditandai dengan penurunan biomarka kolagen tipe I dan IV, $\alpha$-SMA, Snail, Slug, dan fibronektin secara signifikan. ${ }^{51}$

Pada analisis mekanisme tertarget microRNA $26 \mathrm{a} / \mathrm{b}$, penelitian tersebut melakukan identifikasi menggunakan PicTar dan TargetScan 4.2 untuk menganalisis target pada Jagged-1 mutan. Alhasil ditemukan bahwa microRNA 26a/b berikatan secara langsung dengan 2 situs pada untranslated region (UTR) Jagged-1. Hasil ini menunjukkan bahwa efek inhibitor microRNA 26a/b dapat menghambat EMT melalui jalur mekanisme Jagged-1/Notch. ${ }^{51}$

Efek inhibitorik microRNA-26a/b yang dimediasi oleh Jagged-1/Notch akan menghambat kerja Fibroblast Growth Factor (FGF) malaui jalur Mitogen Activated Protein Kinase/Extracelullarsignal-regulated Kinase (MAPK/ERK). Ketika MAPK/ERK dapat dihambat, maka sintesis Notch 2 Intracellular Domain

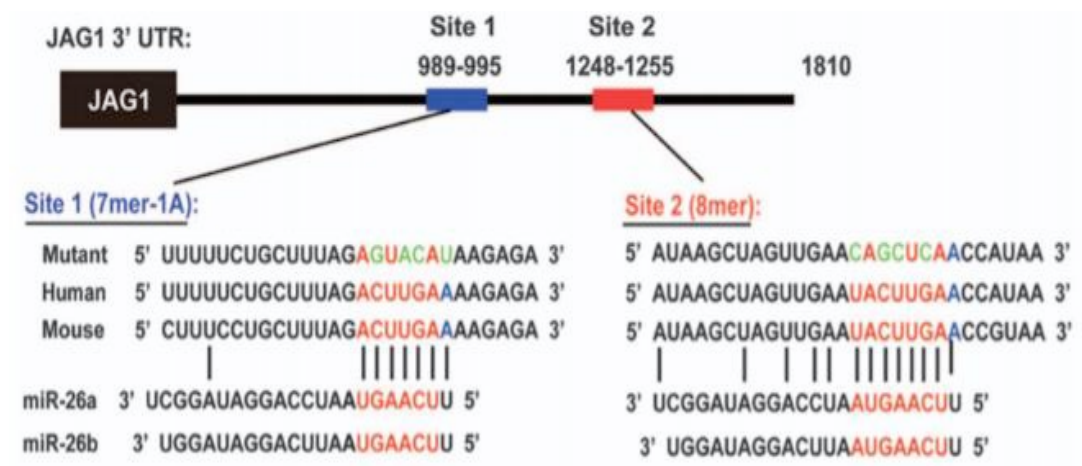

Gambar 3. Analisis target Jagged-1 melalui metodePicTar dan TargetScan 4.2. ${ }^{51}$ 
(N2ICD) dan Hes5 yang merupakan efektor dari Notch juga akan terhambat. Alhasil proses diferensiasi dan proliferasi FGF juga dapat dihambat. ${ }^{52}$

Sementara itu, penelitian Li et al. pada tahun 2015 telah menganalisis level ekspresi dari hsa-microRNA-15a dan hsamicroRNA-16-1 di sel epitel lensa pada pasien katarak akibat faktor penuaan. Penelitian dilakukan pada 60 orang penderita katarak dengan rincian, 20 orang menderita katarak kortikal, 20 orang menderita katarak nuklear, dan 20 orang menderita katarak subscapular posterior. Penelitian tersebut menggunakan PCR untuk mengukur ekspresi dari hsamicroRNA-15a-5p, hsa-microRNA-15a3p, hsa-microRNA-16-1-5p, dan hsamicroRNA-16-1-3p. Adapun gen target dari microRNA tersebut yakni bcl-2 dan mcl-1 juga dievaluasi. Alhasil, Ekspresi dari hsa-microRNA-15a-5p pada katarak kortikal sebesar $8,76 \pm 0,09$, katarak nuklear $14,26 \pm 4,00$, dan 26,39 $\pm 2,07$ untuk katarak subscapular posterior. Ekspresi dari hsa-microRNA-15a-3p, 6,68 $\pm 0,04$ untuk katarak kortikal, 9,07 $\pm 0,06$ untuk katarak nuklear, dan 23,72 \pm 3,59 untuk katarak subscapular posterior. Untuk orang normal hsa-microRNA-15a-5p dan hsamicroRNA-15a-3p berjumlah $1,00 \pm 0,15$ $(\mathrm{P}<0,01) .{ }^{53}$

Untuk hsa-microRNA-16-1-5p paling tinggi terlihat di pasien katarak kortikal yaitu 5,56 $\pm 0,17$ ), katarak nuklear 10,94 \pm 1,49, dan katarak subsscapular posterior $4,29 \pm 0,98 \quad(\mathrm{P}<0,01)$. Untuk hasmicroRNA-16-1-3p, peneliti tidak mendeteksi adanya ekspresi pada katarak kortikal dan katarak nuklear tetapi, terdeteksi $0,01 \pm 0,00$ untuk katarak subscapular posterior. Kadar normal pada lensa orang normal adalah 1,02 $\pm 0,28(\mathrm{P}<$ $0,01) .{ }^{53}$

Untuk hsa-microRNA-16-1-5p paling tinggi terlihat di pasien katarak kortikal yaitu $5,56 \pm 0,17$ ), katarak nuklear 10,94 \pm 1,49, dan katarak subsscapular posterior
$4,29 \pm 0,98 \quad(\mathrm{P}<0,01)$. Untuk hasmicroRNA-16-1-3p, peneliti tidak mendeteksi adanya ekspresi pada katarak kortikal dan katarak nuklear tetapi, terdeteksi $0,01 \pm 0,00$ untuk katarak subscapular posterior. Kadar normal pada lensa orang normal adalah 1,02 $\pm 0,28(\mathrm{P}<$ $0,01) \cdot{ }^{53}$

Ekspresi untuk bc-2 dan mcl-1 menurun bagi ketiga penderita. Bcl-2 dan mcl-1 pada penderita katarak kortikal $0,38 \pm 0,02$ dan $0,24 \pm 0,05$, pada katarak nuklear 0,54 \pm 0,05 dan $0,25 \pm 0,07$, dan untuk katarak subscapular posterior $0,54 \pm 0,54$ dan 0,28 $\pm 0,07$. Kadar bcl-2 dan mcl-1 lensa normal adalah $1,00 \pm 0,05(\mathrm{P}<0,01) .{ }^{53}$

Jika disimpulkan, hasil penelitian tersebut menunjukkan bahwa tingkat ekspresi hsa-microRNA-15a-5p, hsamicroRNA-15a-3p, hsa-microRNA-16-1$5 \mathrm{p}$ yang terdapat pada sel epitel pada pasien katarak ditemukan mengalami peningkatan $(\mathrm{P}<0,01)$. Sedangkan hsamicroRNA-16-1-3p diketahui banyak diekspresikan pada lensa orang normal dan menurun pada lensa penderita katarak $(\mathrm{P}<0,01)$. Sementara gen target microRNA tersebut, yakni bcl-2 dan mcl-1 ditemukan juga mengalami penurunan
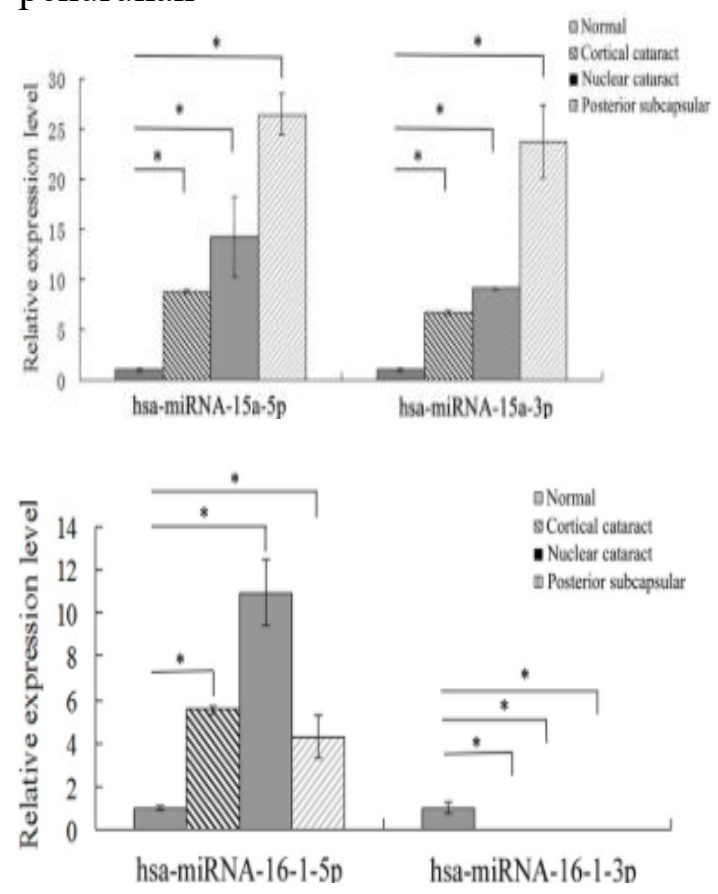


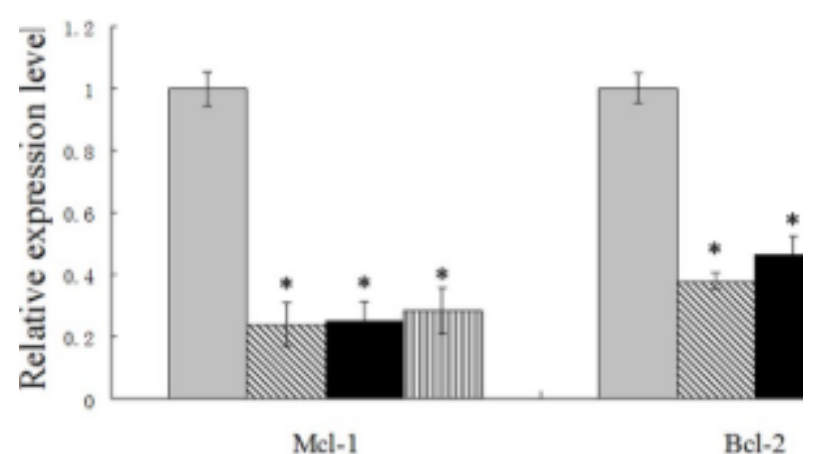

Gambar 4. Analisis ekspresi hsa-microRNA-15a5p, hsa-microRNA-15a-3p, hsa-microRNA-16-15p, dan hsa-microRNA-16-1-3p pada kasus katarak kortikal, katarak nuklear, dan katarak subscapular posterior. ${ }^{53}$

ekspresi pada penderita katarak $(\mathrm{P}<0,01)$. Hasil ini memunculkan sebuah kesimpulan bahwa meningkatnya ekspresi dari hsamicroRNA-15a-5p, hsa-microRNA-15a$3 p$, hsa-microRNA-16-1-5p menekan ekspresi gen anti-apoptosis bcl-2 dan mcl1.53

Baik hsa-microRNA-15a maupun hsamicroRNA-16-1 diketahui bertanggungjawab pada regulasi $14 \%$ dari genom manusia, yang diprediksi mengandung 25.000 gen. hsa-microRNA15a dan hsa-microRNA-16-1 meregulasi secara negatif ekspresi dari anti-apoptosis Bcl-2 dan mcl-1 sehingga mengakibatkan adanya induksi kematian sel malalui jalur apoptosis. Pada dasarnya, kematian pada sel epithelial lensa dapat disebabkan karena adanya paparan sinar UV, kalsium iontophoresis, maupun akumulasi hydrogen peroksida yang dapat mengaktivasi kaskade apoptosis seperti c-Myos, c-Fos, dan caspase 3. Baik Bcl-2 maupun mcl-1 sejatinya merupakan inhibitor dari hydrogen peroksida sehingga bersifat antagonis apotosis. Selain itu, mcl-1 merupakan salah satu faktor maturasi dan perkembangan lensa..$^{53,54}$

Intervensi antagomir microRNA-15a diharapkan dapat memberikan feedback negatif agar ekspresi Bcl-2 dan mcl-1 dapat kembali meningkat. Mekanisme aksi yang mendasari Bcl-2 dan Mcl-1 pada dasarnya cukup sama, hal ini dikarenakan 2 protein antiapoptosis tersebut berasal dari family yang sama. Fakta tentang Bcl-2 yang ditemukan Mao pada sel epitel lensa kelinci menunjukkan bahwa Bcl-2 memiliki resistensi yang tinggi pada prooksidan. Kedua, intervensi antioksidan akan melindungi sel dari apoptosis.

Penelitian tersebut menunjukkan bahwa Bcl-2 resisten terhadap intervensi staurosporine dan camptothecin yang merupakan senyawa peningkat radikal bebas. Meskipun demikian, peningkatan ekspresi Bcl-2 pada sel lensa sample mengakibatkan penurunan protein cystallin yang juga merupakan protektor lensa. Namun, karena resistensi crystalline terhadap radikal bebas rendah, maka Bcl-2 dihipotesakan dapat menggantikan peran antioksidan crystalline. Selain itu, Bcl-2 juga berkaitan dengan ekspresi gen-gen tertentu, seperti halnya p21Bax yang merupakan gen regulator siklus sel. Penelitian Vairo juga menunjukkan bahwa Bcl-2 dapat meningkatkan akumulasi protein p27 dan p130 serta menurunkan protein 107 pada fase G0 ke S sehingga hal ini akan berdampak baik karena dapat menghambat regulasi FGF. Mekanisme yang mendasari Bcl-2 terhadap pengaruhnya pada gen-gen tertentu diketahui dimediasi oleh NF-kB.

Melalui perubahan afinitas $\mathrm{IkBa}$ terhadap NF-kB, maka transaktivasi NF-kB dapat ditingkatkan. NF-kB merupakan jalur persinyalan yang kompleks, sehingga ketika terjadi transaktivasi, maka dimungkinkan adanya pengaruh pada gen lain yang tidak diregulasi langsung oleh Bcl-2, seperti halnya terjadi feedback negatif pada gen p53 dan p21. Mekanisme memungkinkan adanya penghambatan perubahan dari procaspase-3 menjadi caspase 3. Sehingga inaktivasi dari caspase-3 akan membuat tingkat kelangsungan hidup sel meningkat. ${ }^{53,54,55}$ 

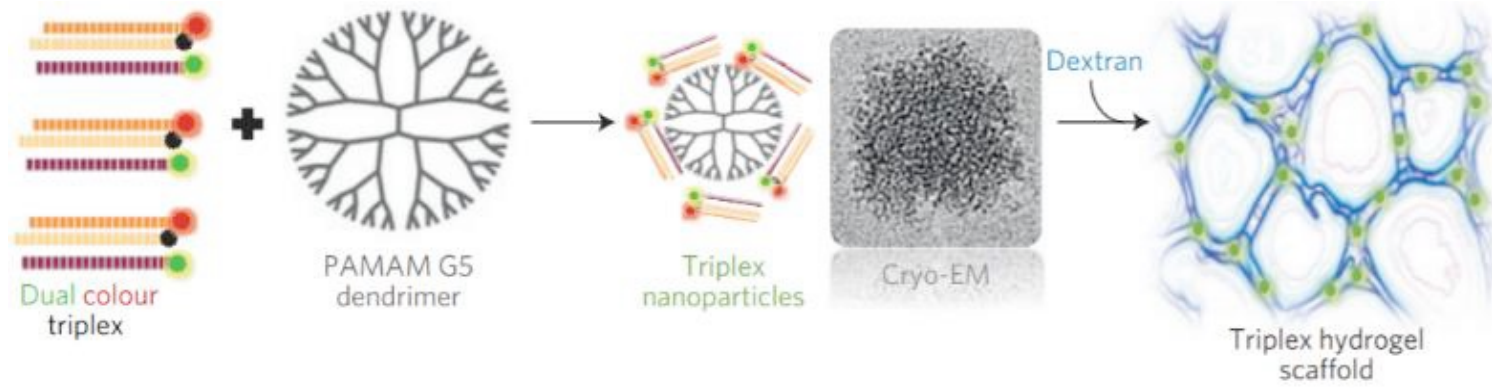

Gambar 5. Ilustrasi karakterisasi RNA triple helix/nanopartikel triplex menggunakan hydrogel scaffold. ${ }^{59}$

Penggunaan terapi berbasis microRNA pada penerapan klinis terbatas pada sistem penghantar yang tidak stabil, biodistribusi yang tidak spesifik, dan efek samping yang tidak terkontrol. Meskipun terdapat beberapa pengembangan metode penghantar microRNA seperti penggunaan nanopartikel inorganik (emas dan magnetik), liposom, lipid, misel, peptida asam nukleat, dan beberapa nanopartikel polimer, namun semuanya mengalami kegagalan dalam pengujian klinik fase II karena memiliki efek peredaman yang minimal. Meskipun demikian, pada awal 2012 telah ditemukan bahwa melalui pembentukan struktur oligonukleotida 3 dimensi, agen imaging dan transfer gen akan menjadi lebih stabil. Pembentukan DNA triple helix sebagai nuklease buatan juga menunjukkan adanya aktivitas pengenalan protein maupun reseptor yang lebih spesifik. ${ }^{56,57,58,59}$

Oleh karena itu, penulis mensintesakan pembentukan RNA triple helix yang telah diuji oleh Conde et al. pada 2015 terhadap microenvironment tumor melalui metode Hydrogel Scaffold. Pembentukan microRNA triple helix membutuhkan 2 microRNA terapeutik yang akan membentuk ikatan Watson-Crick dan ikatan Hoogsteen hydrogen. Triplexforming Oligonucleotides (TFO) yang terbentuk akan berikatan secara antiparallel pada untai RNA yang tersusun dari banyak basa purin, tidak memikiliki aktifitas protonasi (penambahan proton pada suatu atom), dan tidak bergantung pada $\mathrm{pH}$. Dua oligonukleotida microRNA yang terbentuk terdiri dari antagomiR (sebagai efek inhibitorik pada microRNA yang mengalami overekspresi) dan microRNA mimic (sebagai terapi pengganti/replacement microRNA yang mengalami penurunan ekspresi). Kedua microRNA tersebut akan dikonjugasikan dengan dendrimer serta penambahan dextran aldehyde guna meningkatkan kontrol pelepasan microRNA pada gen target. RNA triplex yang tersisntesis akan disemupurnakan dengan polyamidoamine (PAMAM) G5 sehingga akan terlihat struktur nanoscopik yang dapat terlihat pada cryo-electron microscopy atau mikroskop electron dengan resolusi tinggi. ${ }^{59}$

RNA 3 D yang terbentuk akan bereaksi dengan dextran aldehid guna membentuk hydrogel triplex dextrandendrimer-RNA. Penelitian Conde et al. pada tahun 2015 yang membuat struktur triple helix dari microRNA-205 dan antagomir-221 menunjukkan adanya rasio molar 1:1:1 pada suhu ruang di incubator. Pengamatan menggunakan metode gel elektroforesis pada suhu $250 \mathrm{C}$ memiliki rerata migrasi yang lebih lambat dibandingkan dengan bentuk struktur double helix maupun Oligonukleotida single. RNA triple helix juga memiliki nilai melting temperature (Tm) sebesar $74.5 \pm 3.20 \mathrm{C}$, lebih tinggi dibanding struktur single stranded dengan nilai Tm sebesar $55.1 \pm 1.90 \mathrm{C}$ maupun double helix dengan nilai $\mathrm{Tm}$ sebesar $64.8 .1 \pm 2.6$ 0C. Hal ini menunjukkan tingkat stabilitas RNA triple helix baik pada suhu, $\mathrm{pH}$, maupun kadar 
urea tertentu. Pada penelitian tersebut juga dianalisis internalisasi seluler untuk menilai kemampuan RNA triple helix dalam mengintervensi tingkat sel. Analisis ini menggunakan kultur sel MDA-MB-231 TNBC yang menunjukkan bahwa komplek RNA triplex-dendrimer dapat ditransfesikan $100 \%(99.8 \pm 2.5 \%)$ secara spesifik. Pada analisis tersebut terdapat 4 kelompok antara lain Q1 (Sel mengandung dye Quasar 705), Q2 (Sel mangandung dye Quasar 570), Q3 (Mengandung dye Quasar keduanya), dan Q4 sebagai kelompok kontrol negatif. Hasil ini dikonfirmasi dengan Confocal Microscopy selama 24 jam.59

Penelitian Coden (2017) tersebut juga menganalisis mekanisme endositosis RNA triple helix. Secara umum, endositosis dapat terbagi menjadi 3, yakni makropinositosis, Clathrin-dependent endositosis, dan Caveolae-mediated endositosis. Analisis mekanisme endositosis dilakukan dengan menggunakan molekul yang memiliki kemampuan dalam menghambat setiap proses persinyalan intraseluler pada ketiga jalur endositosis tersebut. Inhibitor endositosis yang digunakan antara lain klorpromazie, filipin, rottlerin, brefeldin A, kolsikin, dan kloroquine. Alhasil, ditemukan bahwa RNA triple helix dapat melakukan endositosis via makropinositosis dan Caveole-mediated, meskipun pada jalur caveole-mediated terjadi perubahan ukuran struktur RNA triple helix menjadi $60-80 \mathrm{~nm} .{ }^{59}$

\section{KESIMPULAN DAN SARAN}

\section{Kesimpulan}

Karakterisasi RNA triple helix menggunakan metode Hydrogel Scaffold spesifik terhadap microRNA-15a dan microRNA-26a berpotensi dalam menurunkan laju fibrosis dan menghambat apoptosis pada katarak melalui jalur yang dimediasi oleh Notch, Bcl-2, dan mcl-1 untuk menjadi terapi alternative mutakhir berbasis RNA pada penyakit katarak.

\section{Saran}

Dipelukan analisis karakterisasi konjugasi RNA triple helix dari microRNA-26a dan microRNA-15a serta diperlukan uji klinis agar kedepannya metode terapi berbasis RNA ini dapat diimplementasikan.

\section{DAFTAR PUSTAKA}

1. Shiels A, Fielding Hejtmancik J. Molecular genetics of cataract. eLS. 2001 May 30.

2. Sinha R, Kumar C, Titiyal JS. Etiopathogenesis of cataract: Journal review. Indian journal of ophthalmology. 2009 May;57(3):245.

3. World Health Organization (2013) 'Universal eye health: a global action plan 2014-2019.' ISBN 978924 1506564

4. Prokofyeva, E., Wegener, A., \& Zrenner, E. (2012). Cataract prevalence and prevention in Europe: a literature review. Acta Ophthalmologica, 91(5), 395405.doi:10.1111/j.17553768.2012.02444.x

5. Departemen kesehatan Republik Indonesia, 2017. Deteksi Dini 'Pupil Mata Putih' Cegah Kebutaan pada Anak, Pusat Penyluhuan Kesehatan, Kesehatan Masyarakat Jakarta : Indonesia

6. Tabin G, Chen M, Espandar L. Cataract surgery for the developing world. Current opinion in ophthalmology. 2008 Jan 1;19(1):55-9.

7. Crispim J, Jung LS, Paz L, Allemann N, Schor P. The surgical challenges dense brunescent cataracts present. Expert Review of Ophthalmology. 2015 Jan 2;10(1):13-22.

8. Dubois VD, Bastawrous A. $\mathrm{N}$-acetylcarnosine (NAC) drops for age-related cataract. Cochrane 
Database of Systematic Reviews. 2017(2).

9. Hejtmancik JF, Kantorow M. Molecular genetics of age-related cataract. Experimental eye research. 2004 Jul 1;79(1):3-9.

10. Iorio $\mathrm{MV}$, Croce CM. MicroRNA dysregulation in cancer: diagnostics, monitoring and therapeutics. A comprehensive review. EMBO molecular medicine. 2012 Mar 8;4(3):143-59.

11. Lewis BP, Burge CB, Bartel DP. Conserved seed pairing, often flanked by adenosines, indicates that thousands of human genes are microRNA targets. cell. 2005 Jan 14;120(1):15-20.

12. Dunmire JJ, Lagouros E, Bouhenni RA, Jones M, Edward DP. MicroRNA in aqueous humor from patients with cataract. Experimental eye research. 2013 Mar 1;108:68-71.

13. Lu J, Getz G, Miska EA, AlvarezSaavedra E, Lamb J, Peck D, SweetCordero A, Ebert BL, Mak RH, Ferrando AA, Downing JR. MicroRNA expression profiles classify human cancers. nature. 2005 Jun;435(7043):834.

14. Junn E, Mouradian MM. MicroRNAs in neurodegenerative diseases and their therapeutic potential. Pharmacology \& therapeutics. 2012 Feb 1;133(2):14250.

15. Li Z, Rana TM. Therapeutic targeting of microRNAs: current status and future challenges. Nature reviews Drug discovery. 2014 Aug;13(8):622.

16. Hejtmancik JF, Kaiser-Kupfer MI, Piatigorsky J. Molecular biology and inherited disorders of the eye lens. In: Scriver CR, Beaudet AL, Valle D, editors. The Metabolic and Molecular Basis of Inherited Disease. 8th ed. New York: McGraw Hill; 2001. pp. 6033-62.

17. Semina EV, Ferrell RE, Mintz-Hittner HA, Bitoun P, Alward WL, Reiter RS, Funkhauser $C$, Daack-Hirsch $S$, Murray JC,Harvey Simon, David
Zieve., editors. New York: Time Health Guide; [Last updated and reviewed on 2010 June 23, Last accessed on 16.4.11]

18. Bigsby RM, Cardenas H, CaperellGrant A, Grubbs CJ Proc Natl Acad Sci U S A. 1999 Aug 3; 96(16):932832.Nat Genet. 1998 Jun; 19(2):167-70.

19. Yu X, Lyu D, Dong X, He J, Yao K. Hypertension and risk of cataract: a meta-analysis. PloS one. 2014 Dec 4;9(12):e114012.

20. Mansberger SL, Gordon MO, Jampel H, Bhorade A, Brandt JD, Wilson B, Kass MA, Ocular Hypertension Treatment Study Group. Reduction in intraocular pressure after cataract extraction: the Ocular Hypertension Treatment Study. Ophthalmology. 2012 Sep 1;119(9):1826-31.

21. Kanthan GL, Wang JJ, Rochtchina E, Mitchell P. Use of antihypertensive medications and topical beta-blockers and the long-term incidence of cataract and cataract surgery. British Journal of Ophthalmology. $2009 \quad$ Sep 1;93(9):1210-4.

22. Crasta M, Clode AB, McMullen Jr RJ, Pate DO, Gilger BC. Effect of three treatment protocols on acute ocular hypertension after phacoemulsification and aspiration of cataracts in dogs. Veterinary ophthalmology. 2010 Jan;13(1):14-9.

23. Sharma KK, Santhoshkumar P. Lens aging: effects of crystallins. Biochimica et Biophysica Acta (BBA)-General Subjects. 2009 Oct 1;1790(10):1095-108.

24. Truscott, R. J. 2009 Presbyopia. Emerging from a blur towards an understanding of the molecular basis for this most common eye condition. Exp. Eye Res. 88, $241-247$. (doi:10.1016/j.exer.2008.07.003)

25. Costello, M. J., Johnsen, S., Metlapally, S., Gilliland, K.,

26. Ramamurthy, B., Krishna, P. \& Balasubramanian, D. 2008 Ultrastructural analysis of damage to 
nuclear fiber cell membranes in advanced age-related cataracts from India. Exp. Eye Res. 87, $147-158$.

27. Vrensen, G. F. 2009 Early cortical lens opacities: a short overview. Acta Ophthalmol. 87, 602-610.

28. Lovicu FJ, Shin EH, McAvoy JW. Fibrosis in the lens. Sprouty regulation of TGF $\beta$-signaling prevents lens EMT leading to cataract. Experimental eye research. 2016 Jan 1;142:92-101.

29. Kalluri R, Weinberg RA. The basics of epithelial-mesenchymal transition. The Journal of clinical investigation. 2009 Jun 1;119(6):1420-8.

30. Martinez G, De Iongh RU. The lens epithelium in ocular health and disease. The international journal of biochemistry \& cell biology. 2010 Dec 1;42(12):1945-63.

31. Walker J, Menko AS. Integrins in lens development and disease. Experimental eye research. 2009 Feb 2;88(2):216-25.

32. Eldred JA, Dawes LJ, Wormstone IM. The lens as a model for fibrotic disease. Philosophical Transactions of the Royal Society B: Biological Sciences. 2011 Apr 27;366(1568):1301-19.

33. Chen X, Ye S, Xiao W, Wang W, Luo L, Liu Y. ERK1/2 pathway mediates epithelial-mesenchymal transition by cross-interacting with TGF $\beta /$ Smad and Jagged/Notch signaling pathways in lens epithelial cells. International journal of molecular medicine. 2014 Jun 1;33(6):1664-70.

34. Kopan R, Ilagan MX. The canonical Notch signaling pathway: unfolding the activation mechanism. Cell. 2009 Apr 17;137(2):216-33.

35. Edeling $M$, Ragi G, Huang $S$, Pavenstädt H, Susztak K. Developmental signalling pathways in renal fibrosis: the roles of Notch,Wnt and Hedgehog. Nature Reviews Nephrology. 2016 Jul;12(7):426.

36. Aoyagi-Ikeda $\mathrm{K}$, Maeno $\mathrm{T}$, Matsui $\mathrm{H}$, Ueno M, Hara K, Aoki Y, Aoki F,
Shimizu T, Doi H, Kawai-Kowase K, Iso $T$. Notch Induces Myofibroblast Differentiation of Alveolar Epithelial Cells via Transforming Growth Factor- $\beta-$ Smad3 Pathway. American journal of respiratory cell and molecular biology. 2011 Jul;45(1):136-44.

37. Li L, Xu J, Yang D, Tan X, Wang H. Computational approaches for microRNA studies: a review. Mammalian Genome. 2010 Feb $1 ; 21(1-2): 1-2$.

38. Winter J, Jung S, Keller S, Gregory RI, Diederichs S. Many roads to maturity: microRNA biogenesis pathways and their regulation. Nature cell biology. 2009 Mar;11(3):228.

39. Gregory PA, Bert AG, Paterson EL, Barry SC, Tsykin A, Farshid G et al. The miR-200 family and miR-205 regulate epithelial to mesenchymal transition by targeting ZEB1 and SIP1. Nat Cell Biol 2008; 10: 593-601.

40. Ru P, Steele R, Newhall P, Phillips NJ, Toth K, Ray RB. miRNA-29b suppresses prostate cancer metastasis by regulating epithelial-mesenchymal transition signaling. Mol Cancer Ther 2012; 11: 1166-1173.

41. Siemens H, Jackstadt R, Hunten S, Kaller M, Menssen A, Gotz U et al. miR-34 and SNAIL form a doublenegative feedback loop to regulate epithelial-mesenchymal transitions. Cell Cycle 2011; 10: 4256-4271.

42. Zhou Q, Fan J, Ding X, Peng W, Yu $X$, Chen $Y$ et al. TGF- $\{$ beta $\}$-induced MiR-491-5p expression promotes Par3 degradation in rat proximal tubular epithelial cells. J Biol Chem 2010; 285: 40019-40027

43. Kota J, Chivukula RR, O'Donnell KA, Wentzel EA, Montgomery CL, Hwang HW et al. Therapeutic microRNA delivery suppresses tumorigenesis in a murine liver cancer model. Cell 2009; 137: 1005-1017.

44. Li J, Kong X, Zhang J, Luo Q, Li X, Fang L. MiRNA-26b inhibits 
proliferation by targeting PTGS2 in breast cancer. Cancer Cell Int 2013; 13: 7 .

45. Liu XX, Li XJ, Zhang B, Liang YJ, Zhou CX, Cao DX et al. MicroRNA$26 \mathrm{~b}$ is underexpressed in human breast cancer and induces cell apoptosis by targeting SLC7A11. FEBS Lett 2011; 585: 1363-1367.

46. Wu N, Zhao X, Liu M, Liu H, Yao W, Zhang $\mathrm{Y}$ et al. Role of microRNA-26b in glioma development and its mediated regulation on EphA2. PLoS ONE 2011; 6: e16264.

47. Wei C, Kim IK, Kumar S, Jayasinghe $\mathrm{S}$, Hong $\mathrm{N}$, Castoldi $\mathrm{G}$ et al. NFkappaB mediated miR-26a regulation in cardiac fibrosis. J Cell Physiol 2013; 228: 1433-1442.

48. Liang $\mathrm{H}, \mathrm{Gu} \mathrm{Y}$, Li $\mathrm{T}$, Zhang $\mathrm{Y}$, Huangfu $\mathrm{L}, \mathrm{Hu} \mathrm{M}$ et al. Integrated analyses identify the involvement of microRNA-26a in epithelialmesenchymal transition during idiopathic pulmonary fibrosis. Cell Death Dis 2014; 5: e1238.

49. Wang Y, Li W, Zang X, Chen N, Liu T, Tsonis PA et al. MicroRNA-204-5p regulates epithelialto-mesenchymal transition during human posterior capsule opacification by targeting SMAD4. Invest Ophthalmol Vis Sci 2013; 54: 323-332.

50. Dong $\mathrm{N}, \mathrm{Xu} \mathrm{B}$, Benya SR, Tang X. MiRNA-26b inhibits the proliferation, migration, and epithelial-mesenchymal transition of lens epithelial cells. Mol Cell Biochem 2014; 396: 229-238.

51. Chen X, Xiao W, Chen W, Liu X, Wu M, Bo Q, Luo Y, Ye S, Cao Y, Liu Y. MicroRNA-26a and-26b inhibit lens fibrosis and cataract by negatively regulating Jagged-1/Notch signaling pathway. Cell death and differentiation. 2017 Aug;24(8):1431.

52. Saravanamuthu SS, Gao CY, Zelenka PS. Notch signaling is required for lateral induction of Jagged1 during FGF-induced lens fiber differentiation.
Developmental biology. 2009 Aug 1;332(1):166-76.

53. Li Y, Liu S, Zhang F, Jiang $\mathrm{P}, \mathrm{Wu} X$, Liang $Y$. Expression of the microRNAs hsa-miR-15a and hsamiR-16-1 in lens epithelial cells of patients with age-related cataract. International journal of clinical and experimental medicine. 2015;8(2):2405.

54. Liu SJ, Wang WT, Zhang FL, Yu YH, Yu HJ, Liang Y, Li N, Li YB. miR$15 a-3 p$ affects the proliferation, migration and apoptosis of lens epithelial cells. Molecular medicine reports. 2019 Feb 1;19(2):1110-6.

55. Mao YW, Xiang $\mathrm{H}$, Wang J, Korsmeyer S, Reddan J, Li DW. Human bcl-2 gene attenuates the ability of rabbit lens epithelial cells against H2O2-induced apoptosis through down-regulation of the $\alpha \mathrm{B}$ crystallin gene. Journal of Biological Chemistry. $\quad 2001 \quad$ Nov 16;276(46):43435-45.

56. Lee HM, Nguyen DT, Lu LF. Progress and challenge of microRNA research in immunity. Frontiers in genetics. 2014 Jun 12;5:178.

57. Sethupathy $P$. The promise and challenge of therapeutic microRNA silencing in diabetes and metabolic diseases. Current diabetes reports. 2016 Jun 1;16(6):52.

58. Andreasen D, Fog JU, Biggs W, Salomon J, Dahslveen IK, Baker A, Mouritzen P. Improved microRNA quantification in total RNA from clinical samples. Methods. 2010 Apr 1;50(4):S6-9.

59. Conde J, Oliva N, Atilano M, Song HS, Artzi N. Self-assembled RNAtriple-helix hydrogel scaffold for microRNA modulation in the tumour microenvironment. Nature materials. 2016 Mar;15(3):353.penulisan 